\title{
Heterovalent Cation Substitutional and Interstitial Doping in Semiconductor Sensitizers for Quantum Dot Cosensitized Solar Cell
}

\author{
Ningning Zhang, Xiaoping Zou, and Yanyan Gao \\ Beijing Key Laboratory for Sensor, Ministry of Education Key Laboratory for Modern Measurement and Control Technology, \\ and School of Applied Sciences, Beijing Information Science and Technology University, Jianxiangqiao Campus, Beijing 100101, China
}

Correspondence should be addressed to Xiaoping Zou; xpzou2005@gmail.com

Received 12 June 2014; Revised 26 November 2014; Accepted 19 December 2014

Academic Editor: Serap Gunes

Copyright (C) 2015 Ningning Zhang et al. This is an open access article distributed under the Creative Commons Attribution License, which permits unrestricted use, distribution, and reproduction in any medium, provided the original work is properly cited.

\begin{abstract}
Doped films of $\mathrm{TiO}_{2} / \mathrm{PbS} / \mathrm{CdS}$ have been prepared by successive ionic layer adsorption and reaction (SILAR) method. Bi- and Agdoped-PbS quantum dot (QD) were produced by admixing $\mathrm{Bi}^{3+}$ or $\mathrm{Ag}^{+}$during deposition and the existing forms of the doping element in $\mathrm{PbS} \mathrm{QD}$ were analyzed. The results show that $\mathrm{Bi}^{3+}$ entered the cube space of $\mathrm{PbS}$ as donor yielding interstitial doping Bi-doped-PbS QD, while $\mathrm{Ag}^{+}$replaced $\mathrm{Pb}^{2+}$ of $\mathrm{PbS}$ as acceptor yielding substitutional doping Ag-doped-PbS QD. The novel Bidoped-PbS/CdS and Ag-doped-PbS/CdS quantum dot cosensitized solar cell (QDCSC) were fabricated and power conversion efficiency (PCE) of $2.4 \%$ and $2.2 \%$ was achieved, respectively, under full sun illumination.
\end{abstract}

\section{Introduction}

Growing attention has been paid to quantum dots for their remarkable characteristics of high absorption coefficient, tunable band gap, and multiple exciton generation (MEG) effect [1-4]. In theory, the PCE of QDSSCs could reach to $66 \%$ [5]; however, the actual PCE of QDSSC is not ideal at present. Introducing impurity into QD sensitizer can successfully improve the performance of QDSSC [6-9]. Using this method, CdSe QDs and Mg-doped CdSe QDs deposited on $\mathrm{TiO}_{2}$ electrode displayed a broad spectral response [6] and $\mathrm{Mn}$-doped CdS created electronic states in the midgap region of the CdS QD [7], while they did not give the existing form of doping elements. Lee group reported a $\mathrm{PbS}: \mathrm{Hg} \mathrm{QD}$-sensitized solar cell with an unprecedentedly high $J_{\mathrm{SC}}$ of $30 \mathrm{~mA} / \mathrm{cm}^{2}$, owing to reinforcing $\mathrm{Pb}-\mathrm{S}$ bond via incorporation of $\mathrm{Hg}^{2+}$ ion into the interstitial site of $\mathrm{PbS}$ lattice and broadening the absorption spectrum [8] and encouraging power conversion efficiency have been achieved on such devices.

For semiconductor nanocrystals (NCs), a single dopant which entered into NCs introduces impurity levels [10]. In the case of multiple impurities in a single dot, the nature of delocalization and interaction of the impurity charge carriers may be greatly modified relative to the bulk case [11]. The effects of doping on QD are akin to the influence of impurity on NCs, in virtue of QD which have a stronger confinement effect. In this report, $\mathrm{Bi}^{3+}$ and $\mathrm{Ag}^{+}$were heavily doped into $\mathrm{PbS} \mathrm{QD}$ and created impurity energy band in the band gap of PbS QD.

Herein, Bi- and Ag-doped-PbS quantum dot (QD) were produced by admixing $\mathrm{Bi}^{3+}$ or $\mathrm{Ag}^{+}$with SILAR method and the existing forms of the doping element in $\mathrm{PbS} \mathrm{QD}$ were analyzed. Optical measurements, Hall measurement, and XPS coupled with theoretical analysis showed that $\mathrm{Bi}^{3+}$ entered the cube space of $\mathrm{PbS}$ as donor yielding interstitial doping Bi-doped-PbS QD, while $\mathrm{Ag}^{+}$replaced $\mathrm{Pb}^{2+}$ of $\mathrm{PbS}$ as acceptor yielding substitutional doping Ag-doped-PbS QD. The novel quantum dot cosensitized solar cell (QDCSC) with a photoanode of $\mathrm{TiO}_{2}$-Bi-doped-PbS/CdS or $\mathrm{TiO}_{2} / \mathrm{Ag}$-doped$\mathrm{PbS} / \mathrm{CdS}, \mathrm{Cu}_{2} \mathrm{~S}$ counter electrode, and sulfide/polysulfide electrolyte was fabricated and power conversion efficiency (PCE) of $2.4 \%$ and $2.2 \%$ was achieved, respectively, under full sun illumination, which were higher than undoped $\mathrm{TiO}_{2} / \mathrm{PbS} / \mathrm{CdS}$. By Uv-Vis and UPS measurements, we noted 
TABle 1: Content of atoms in $\mathrm{TiO}_{2} / \mathrm{Bi}$-doped-PbS and $\mathrm{TiO}_{2} / \mathrm{Ag}$-doped-PbS solid film.

\begin{tabular}{|c|c|c|c|c|c|}
\hline Sample & $M_{\mathrm{Pb}}{ }^{\mathrm{a}} / \%$ & $M_{\mathrm{Bi}}^{\mathrm{b}} / \%$ & $M_{\mathrm{Cd}}{ }^{\mathrm{c}} / \%$ & $M_{\mathrm{S}}^{\mathrm{d}} / \%$ & $M_{\mathrm{Ag}}^{\mathrm{e}} / \%$ \\
\hline $\mathrm{TiO}_{2} / \mathrm{PbS}: \mathrm{Bi} / \mathrm{CdS}$ & 12.56 & 0.0407 & 22.69 & 5.555 & - \\
\hline $\mathrm{TiO}_{2} / \mathrm{PbS}: \mathrm{Ag} / \mathrm{CdS}$ & 8.216 & - & 17.61 & 4.497 & 0.234 \\
\hline
\end{tabular}

that the changes in energy band of QD lead to the differences in the performance of the QDCSC. The research has a great importance on the development of QDSSC.

\section{Materials and Methods}

2.1. Sensitization of QD on Mesoporous $\mathrm{TiO}_{2}$ Film. First, FTOcoated glass substrates were cleaned by ultrasonication in an alkaline, aqueous washing solution, rinsed with deionized water, ethanol, and acetone, and dried with nitrogen. The substrates were treated in an $0.04 \mathrm{M}$ aqueous solution of $\mathrm{TiCl}_{4}$ for $30 \mathrm{~min}$ at $70^{\circ} \mathrm{C}$, rinsed with deionized water, and dried at $450^{\circ} \mathrm{C}$ for $30 \mathrm{~min}$. After cooling to room temperature $\left(25^{\circ} \mathrm{C}\right)$, the mesoporous $\mathrm{TiO}_{2}$ layer composed of 20 -nmsized particles was deposited on substrates by using doctorblade method and annealed at $450^{\circ} \mathrm{C}$ for $30 \mathrm{~min}$. Successive ionic layer adsorption and reaction (SILAR) method was employed to sensitize $\mathrm{TiO}_{2}$ mesoporous film with QD. Briefly, mesoporous $\mathrm{TiO}_{2}$ coated electrode was first dipped in ethanol and deionized water $(1: 1)$ solution of $0.1 \mathrm{M} \mathrm{Pb}\left(\mathrm{NO}_{3}\right)_{2}$ for $1 \mathrm{~min}$, followed by dipping in methanol solution of $0.1 \mathrm{M}$ $\mathrm{Na}_{2} \mathrm{~S}$ for $1 \mathrm{~min}$. Between each dipping, the electrode was thoroughly washed with ethanol or methanol and dried with nitrogen. These processes were defined as one cycle. Then, the $\mathrm{TiO}_{2}$ substrate electrodes deposited with $\mathrm{PbS}$ were successively dipped in ethanol solution of $0.1 \mathrm{M} \mathrm{Cd}\left(\mathrm{NO}_{3}\right)_{2}$ for $5 \mathrm{~min}$ and methanol solution of $0.1 \mathrm{M} \mathrm{Na}_{2} \mathrm{~S}$ for another $5 \mathrm{~min}$. Between each dipping, the electrode was thoroughly washed with ethanol or methanol and dried with nitrogen. For Bidoped-PbS and Ag-doped-PbS QD, $5 \mathrm{mmol}$ of $\mathrm{BiCl}_{3}$ and $6.7 \mathrm{mmol} \mathrm{AgNO}_{3}$ were added to $\mathrm{Pb}\left(\mathrm{NO}_{3}\right)_{2}$ cationic precursor solution, respectively. To obtain the optimum photovoltaic performance in each condition, several coating cycles were repeated ( 2 cycles for $\mathrm{PbS}, \mathrm{Bi}$-doped-PbS, and $\mathrm{Ag}$-doped-PbS, 6 cycles for CdS of Ag-doped-PbS/CdS, and 7 cycles for CdS of Bi-doped-PbS/CdS).

2.2. Solar Cell Fabrication. The polishing brass plate was cleaned by ultrasonication in an alkaline, rinsed with deionized water, ethanol, isopropanol, and acetone (volume ratio was $8: 2$ ), and dried with nitrogen. The clean brass plate was etched in hydrochloric acid $(35.0 \sim 37.0 \%)$ at $80^{\circ} \mathrm{C}$ for $30 \mathrm{~min}$ and subsequently washed with deionized water and dried with nitrogen. Polysulfide electrolyte solution composed of $1 \mathrm{M} \mathrm{Na} \mathrm{N}_{2} \mathrm{~S}, 1 \mathrm{M} \mathrm{S}$, and $0.1 \mathrm{M} \mathrm{NaOH}$ in deionized water was dropped on etched brass for 15-30 min and black colored $\mathrm{Cu}_{2} \mathrm{~S}$ formed on the brass foil. The QDs sensitized $\mathrm{TiO}_{2}$ electrode and $\mathrm{Cu}_{2} \mathrm{~S}$ counter electrode were assembled using $60 \mathrm{~mm}$ thick sealing materials. Polysulfide electrolyte solution was injected into the gap between photoanode and counter electrode from the side using injector. The active area was $0.25 \mathrm{~cm}^{2}$.

\section{Results and Discussion}

Field emission scanning electron microscope (FESEM, Hitachi S-4800) was used to characterize the morphology of the samples. As revealed by SEM images (Figures 1(a), 1(b), 1(c), and 1(d)), mesoporous films were deposited on FTO glass. By comparing the SEM images of $\mathrm{TiO}_{2} / \mathrm{Bi}$-doped-PbS (Figure $1(\mathrm{a})$ ) and $\mathrm{TiO}_{2} / \mathrm{Bi}$-doped$\mathrm{PbS} / \mathrm{CdS}$ (Figure 1(b)), $\mathrm{TiO}_{2} /$ Ag-doped-PbS (Figure 1(c)), and $\mathrm{TiO}_{2} /$ Ag-doped-PbS/CdS (Figure $1(\mathrm{~d})$ ), the pore size distribution of mesoporous films decreased after the deposit of CdS QDs, which confirm that the cosensitized QDs formed. Energy dispersive X-ray spectrum (EDS) was collected to investigate the composition of the mesoporous films. According to the corresponding EDS spectra, the elements $\mathrm{Bi}$ and Ag exist in the mesoporous films. To further determine and analyse the elements in the mesoporous films, the inductively coupled plasma optical emission spectroscopy (ICP-OES) measurement was used. The results revealed that the elements $\mathrm{Bi}$ and $\mathrm{Ag}$ exist in the corresponding mesoporous films (Table 1), in agreement with the results obtained with EDS.

The black, red, blue, and green curves in Figure 2(a) show X-ray powder diffraction spectra of $\mathrm{TiO}_{2}$ mesoporous films deposited with the pure $\mathrm{PbS}, \mathrm{Bi}$-doped-PbS, and Ag-doped$\mathrm{PbS}$, respectively. For comparison, we find six additional diffraction peaks that do not originate from $\mathrm{TiO}_{2}$, suggesting the $\mathrm{PbS}$ crystal growth on the $\mathrm{TiO}_{2}$ mesoporous film. In addition, new diffraction peak does not appear with $\mathrm{Bi}$ doped-PbS and Ag-doped-PbS, which suggests that no new substance is formed after doping with cation $\mathrm{Bi}^{3+}$ and $\mathrm{Ag}^{+}$. However, a slight broadening of (311) crystal surfaces of Bidoped-PbS is caused by the size change after doping cation $\mathrm{Bi}^{3+}$. According to Figure 2(b), Bi-doped-PbS/CdS and Agdoped-PbS/CdS cosensitized QDs have been successfully deposited on mesoporous $\mathrm{TiO}_{2}$ films, respectively.

The PbS, Bi-doped-PbS, and Ag-doped-PbS QDs sensitized mesoporous $\mathrm{TiO}_{2}$ films were also characterized with a transmission electron microscope (TEM, FEI, Tecnai F20UT) operating at $200 \mathrm{KV}$, to investigate impact of doping on $\mathrm{PbS}$ QD. TEM images show very clear lattice fringes from the QDs (Figure 3). It is obviously that the size of Bi-doped-PbS (Figure 3(b)) QD is smaller than that of PbS QD (Figure 3(a)), while the size of Bi-doped-PbS QD (Figure 3(c)) is equal to that of $\mathrm{PbS} \mathrm{QD}$. This means that $\mathrm{Bi}$ impurity causes the lattice contraction of $\mathrm{PbS}$ and $\mathrm{Ag}$ impurity has no effect on the lattices of $\mathrm{PbS}$, in agreement with the results obtained with XRD. X-ray photoelectron spectroscopy (XPS) analysis of $\mathrm{PbS}, \mathrm{Bi}$-doped-PbS, and Ag-doped-PbS QDs adsorbed on 


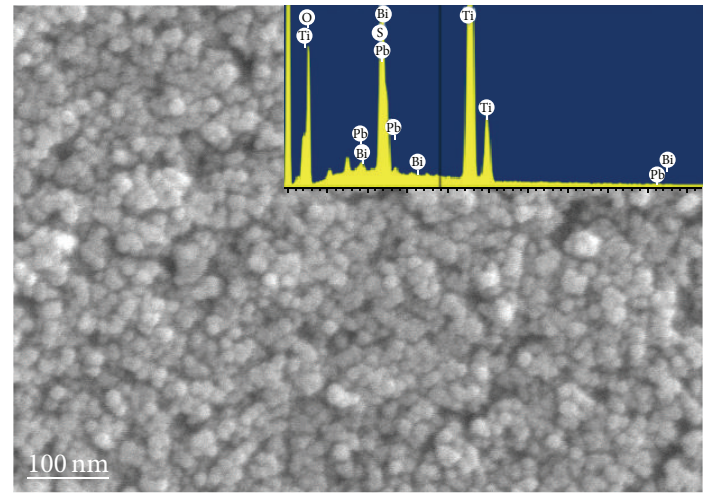

(a)

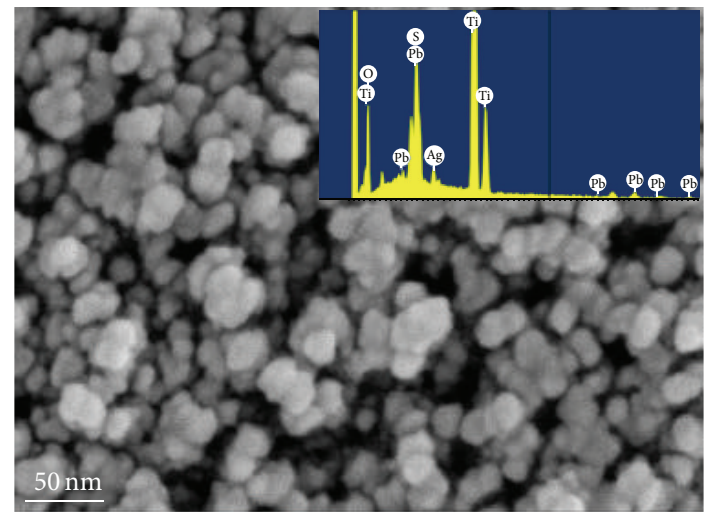

(c)

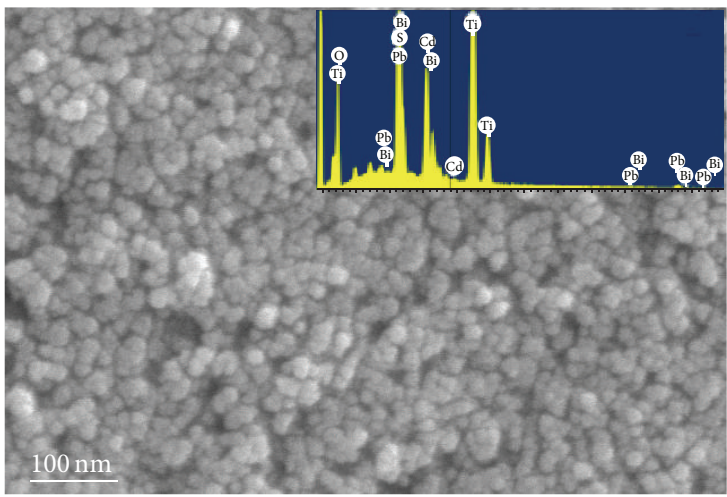

(b)

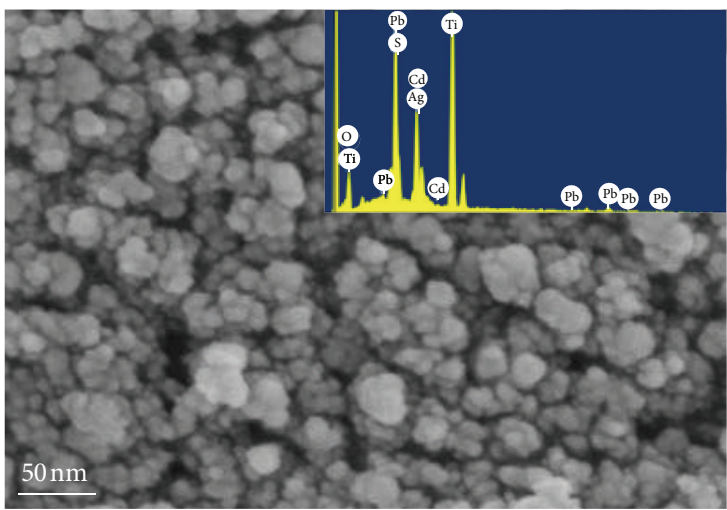

(d)

Figure 1: SEM images of $\mathrm{TiO}_{2} / \mathrm{Bi}$-doped-PbS, $\mathrm{TiO}_{2} / \mathrm{Bi}$-doped-PbS/CdS, $\mathrm{TiO}_{2} / \mathrm{Ag}$-doped-PbS, and $\mathrm{TiO}_{2} / \mathrm{Ag}$-doped-PbS/CdS. Insets in images are corresponding EDS spectra.

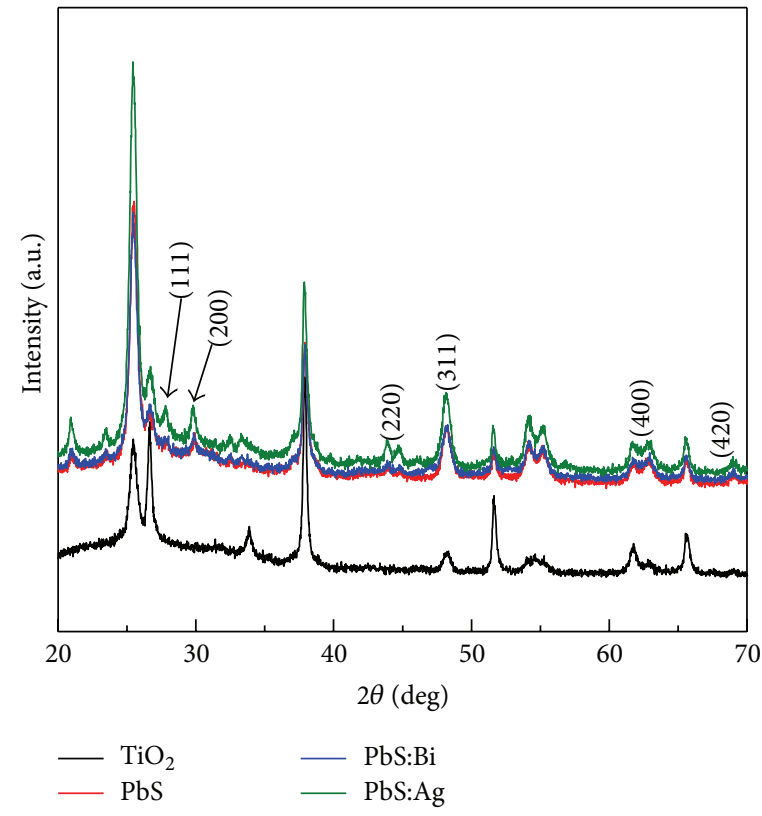

(a)

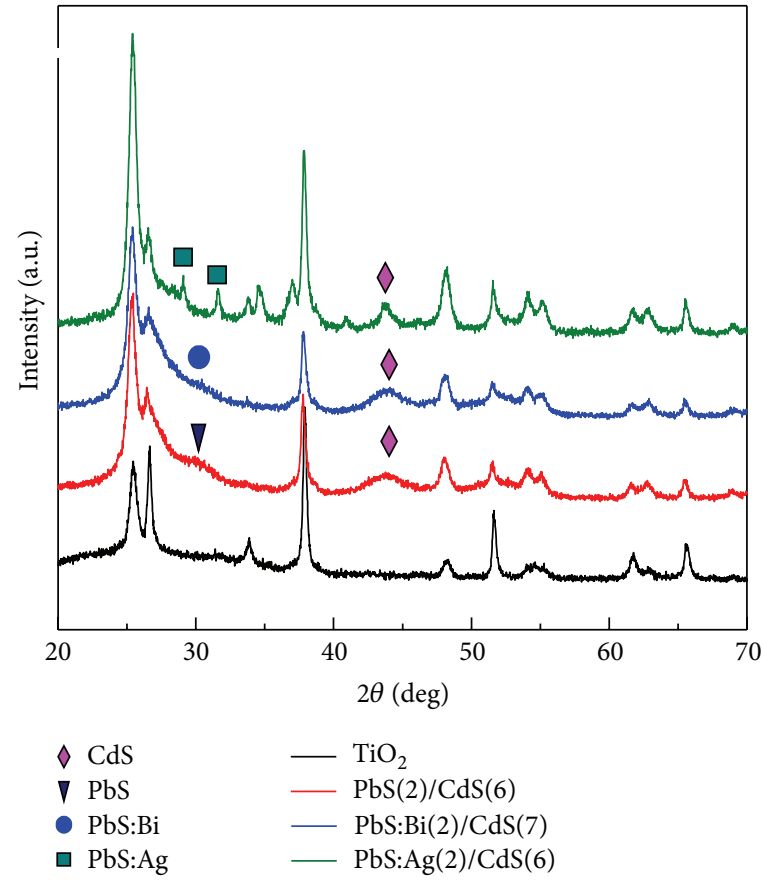

(b)

FIgURE 2: XRD patterns of $\mathrm{TiO}_{2}$, Bi-doped-PbS, Ag-doped-PbS, Bi-doped-PbS/CdS, and Ag-doped-PbS/CdS. 


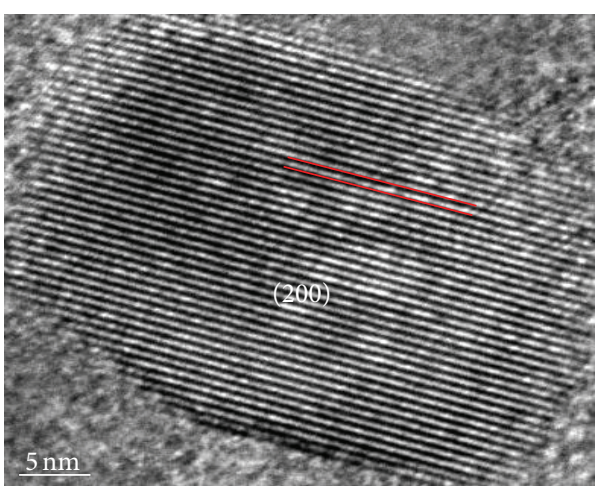

(a)

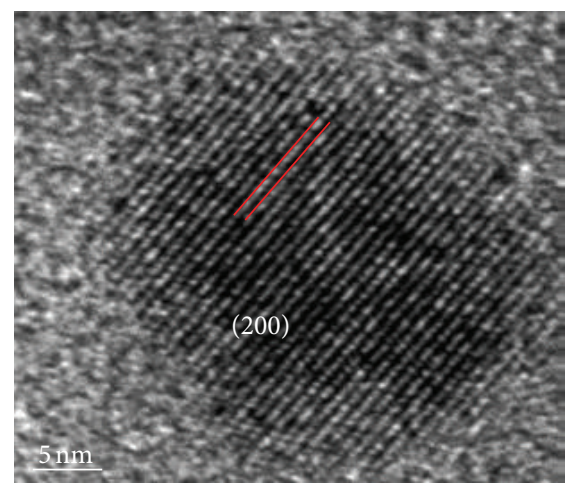

(b)

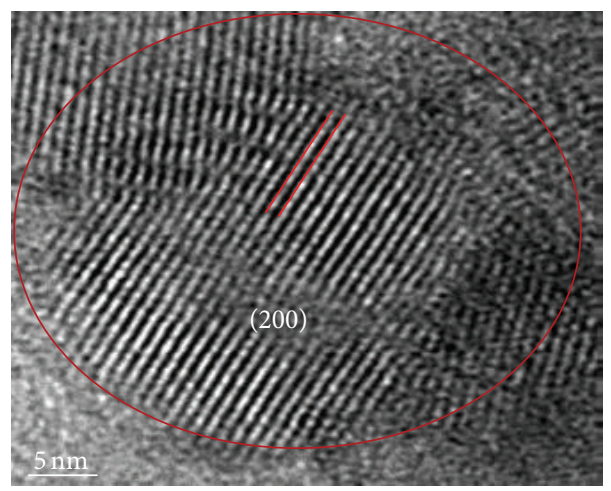

(c)

FIgUre 3: TEM images of (a) PbS, (b) Bi-doped-PbS, and (c) Ag-doped-PbS QDs.

TABLE 2: Valence state parameters of elements in PbS, Bi-doped-PbS, and Ag-doped-PbS QDs.

\begin{tabular}{lccc}
\hline Element & Binding energy & Valence state & Valence \\
\hline $\mathrm{S}$ & 160.67 & $2 \mathrm{p}$ & -2 \\
$\mathrm{~Pb}$ & 138.32 & $4 \mathrm{f} 7$ & +2 \\
$\mathrm{Bi}$ & 157.86 & $4 \mathrm{f} 7$ & +3 \\
$\mathrm{Ag}$ & 367.5 & $3 \mathrm{~d} 5$ & $+1,+2$ \\
\hline
\end{tabular}

mesoporous $\mathrm{TiO}_{2}$ surface was also performed (Figure 4). By analyzing XPS (Table 2), the valence state of elements $\mathrm{S}, \mathrm{Pb}$, $\mathrm{Bi}$, and $\mathrm{Ag}$ is $-2,+2,+3$, and +1 (the relatively stable valence of Ag element is +1 [11]), respectively.

Semiconductor doping is the process that changes an intrinsic semiconductor to an extrinsic semiconductor. Hall measurement suggests that $\mathrm{PbS}, \mathrm{Bi}$-doped-PbS, and Agdoped-PbS are p-type, n-type, and p-type semiconductor (Table 3), respectively. It demonstrates that $\mathrm{Bi}$ impurities "donate" their extra valence electrons to conduction band of $\mathrm{PbS}$, providing excess electrons to $\mathrm{PbS}$. Excess electrons increase the electron carrier concentration of $\mathrm{PbS}$, forming impurity energy band which lies closer to the conduction band than the valence band. However, Ag impurities "accept" electrons from the valence band of PbS. Excess holes increase the hole carrier concentration of $\mathrm{PbS}$, forming impurity energy band which lies closer to the valence conduction band than the conduction band.
The diffuse reflection absorption spectra of QDs are shown in Figure 5(a). After doping impurities, a broad band appeared at near infrared region which is observed for $\mathrm{Bi}$ doped-PbS and Ag-doped-PbS QD, which can be attributed to heavily doped $\mathrm{Bi}$ or Ag impurities that formed impurity band in the band gap of PbS. For Bi-doped-PbS based on mesoporous $\mathrm{TiO}_{2}$ film, the optical absorption of Bi-doped$\mathrm{PbS}$ was significantly enhanced in the visible light which is obvious, indicating that $\mathrm{Bi}$-doped-PbS can generate more photogenerated electrons. In addition, Bi-doped-PbS QDs show the obvious blue shift in the absorption spectra due to the increase in the bulk energy band gap. In general, the shift of the onset absorption to lower wavelengths with decreasing particle size represents size quantization effects in these particles [12]. For Ag-doped-PbS, there is no obvious change expect for a broad band at near infrared region, suggesting that the size of $\mathrm{PbS}$ is unchanged after doping Ag impurities. These results are in agreement with the results obtained with XRD and TEM.

Optical band gap of the QDs was estimated from diffuse reflection absorption spectra using $\alpha h v=A\left(h v-E_{g}\right)^{2}$ equation [13]. As shown in Figure 5(b), the optical band gap of PbS, Bi-doped-PbS, and Ag-doped-PbS QD is $1.05 \mathrm{eV}$, $1.2 \mathrm{eV}$, and $1.07 \mathrm{eV}$, respectively. Ultraviolet photoelectron spectroscopy (UPS) can determine valence band maximum (VBM) [14]. Secondary cut-off is fitted to energy of He I light source $(21.2 \mathrm{eV})$, where extrapolation of low energy region corresponds to potential energy of VBM from the 


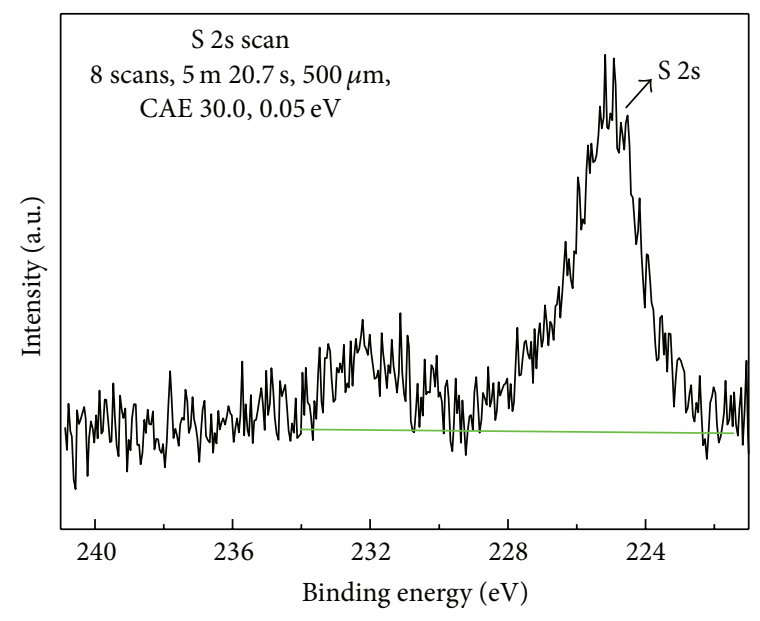

(a)

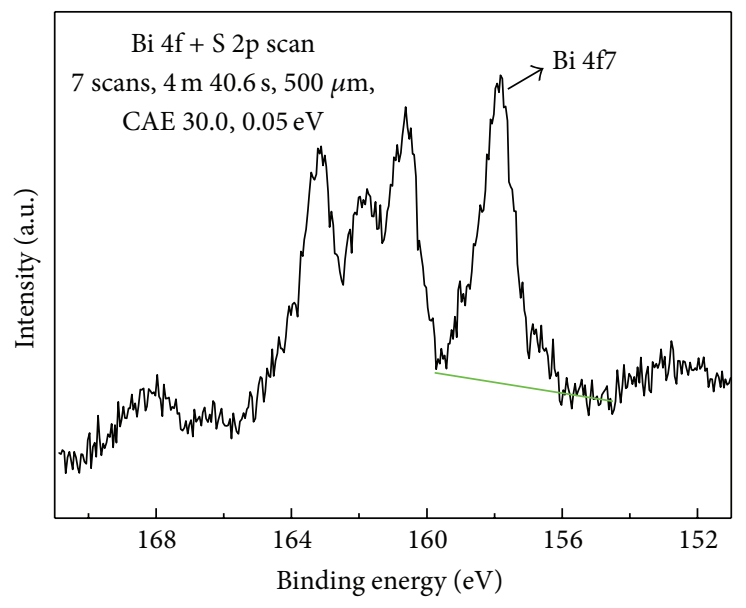

(c)

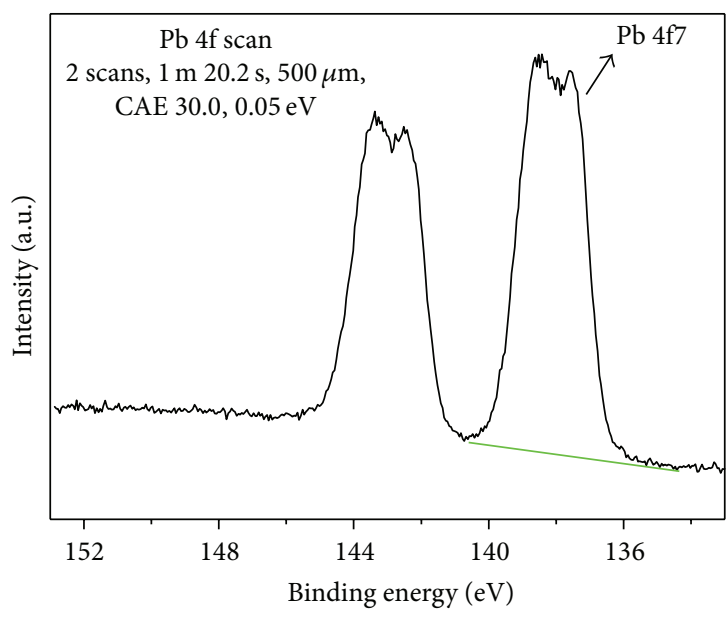

(b)

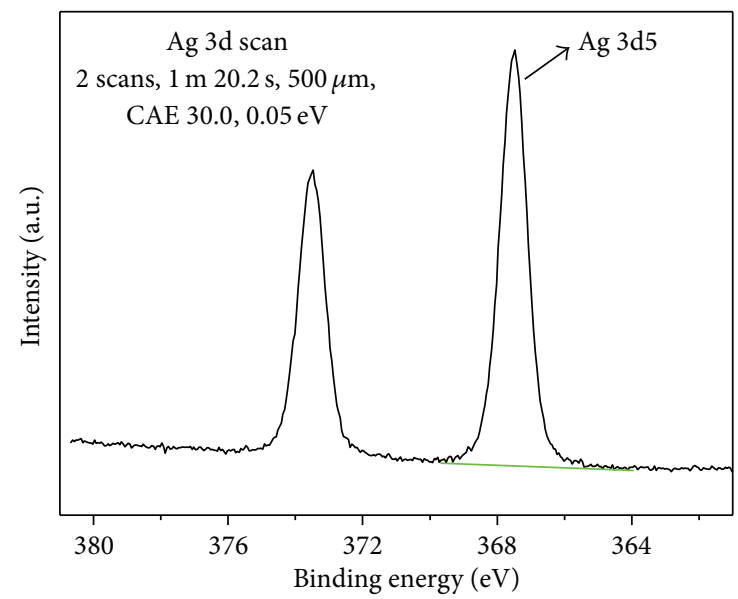

(d)

FIGURE 4: XPS of (a) S 2s peaks, (b) Pb 4f peaks, (c) Bi 4f peaks, and (d) Ag 3d peaks for PbS, Bi-doped-PbS, and Ag-doped-PbS QDs adsorbed on mesoporous $\mathrm{TiO}_{2}$ surface.

TABLE 3: Resistivity, Hall coefficient, conductivity type, carrier density, and Hall mobility of PbS:Hg thin film using Hall effect measurement system. The measurement conducted at room temperature under applied field was adjusted from 1 to $5 \mathrm{kG}$.

\begin{tabular}{|c|c|c|c|c|c|c|}
\hline Sample & $\begin{array}{l}\text { Field } \\
{[\mathrm{Gs}]}\end{array}$ & $\begin{array}{l}\text { Resistivity } \\
{[\mathrm{ohm} \cdot \mathrm{cm}]}\end{array}$ & $\begin{array}{c}\text { Hall coefficient } \\
{\left[\mathrm{cm}^{3} / \mathrm{C}\right]}\end{array}$ & Type & $\begin{array}{c}\text { Carrier density } \\
{\left[1 / \mathrm{cm}^{3}\right]}\end{array}$ & $\begin{array}{l}\text { Hall mobility } \\
{\left[\mathrm{cm}^{2} /(\mathrm{V} \cdot \mathrm{s})\right]}\end{array}$ \\
\hline $\mathrm{TiO}_{2}$ & 3000 & $-3.6201 \times 10^{2}$ & $-2.34155 \times 10^{6}$ & $\mathrm{n}$ & $2.6692 \times 10^{12}$ & $6.4682 \times 10^{3}$ \\
\hline $\mathrm{TiO}_{2} / \mathrm{PbS}$ & 3000 & $-7.4174 \times 10^{2}$ & $1.56716 \times 10^{6}$ & $\mathrm{p}$ & $3.9881 \times 10^{12}$ & $2.1128 \times 10^{3}$ \\
\hline $\mathrm{TiO}_{2} / \mathrm{PbS}: \mathrm{Bi}$ & 3000 & $6.3436 \times 10^{4}$ & $-8.08514 \times 10^{3}$ & $\mathrm{n}$ & $7.7302 \times 10^{14}$ & $1.2745 \times 10^{1}$ \\
\hline $\mathrm{TiO}_{2} / \mathrm{PbS}: \mathrm{Ag}$ & 3000 & $1.5702 \times 10^{5}$ & $4.73004 \times 10^{3}$ & $\mathrm{P}$ & $1.3213 \times 10^{15}$ & $3.0123 \times 10^{2}$ \\
\hline
\end{tabular}

vacuum level $[8,14]$ (Figure 5(b)). The position of conduction band minimum (CBM) is estimated based on VBM and optical band gap energy [8]. Heavily doped Bi-doped-PbS QD is n-type semiconductor, so the impurity band is near to CBM (Figure 6(a)), while the impurity band is near to VBM of heavily doped Ag-doped-PbS QD because it is p-type semiconductor. Band edge alignment is shown in Figure 6, where CBMs of the doped QDs move upward relative to pure QDs.
Figure 7(a) shows diffuse reflection absorption spectra of QDs cosensitized mesoporous $\mathrm{TiO}_{2}$ films. Photocurrent density-voltage $(J-V)$ curves of the QDCSCs based on $\mathrm{TiO}_{2} / \mathrm{PbS}(2) / \mathrm{CdS}(7), \mathrm{TiO}_{2} / \mathrm{Bi}$-doped-PbS(2)/CdS(7), $\mathrm{TiO}_{2} /$ $\mathrm{PbS}(2) / \mathrm{CdS}(6)$, and $\mathrm{TiO}_{2} / \mathrm{Ag}$-doped-PbS(2)/CdS(6) were presented in Figure $7(\mathrm{~b})$. We show the solar cell performance parameters in Table 4 . By comparing with the corresponding undoped system, $J_{\mathrm{SC}}$ of QDCSC is essentially increased after doping $\mathrm{Bi}$ or Ag impurities into PbS QDs. The $J_{\mathrm{SC}}$ of the cell 


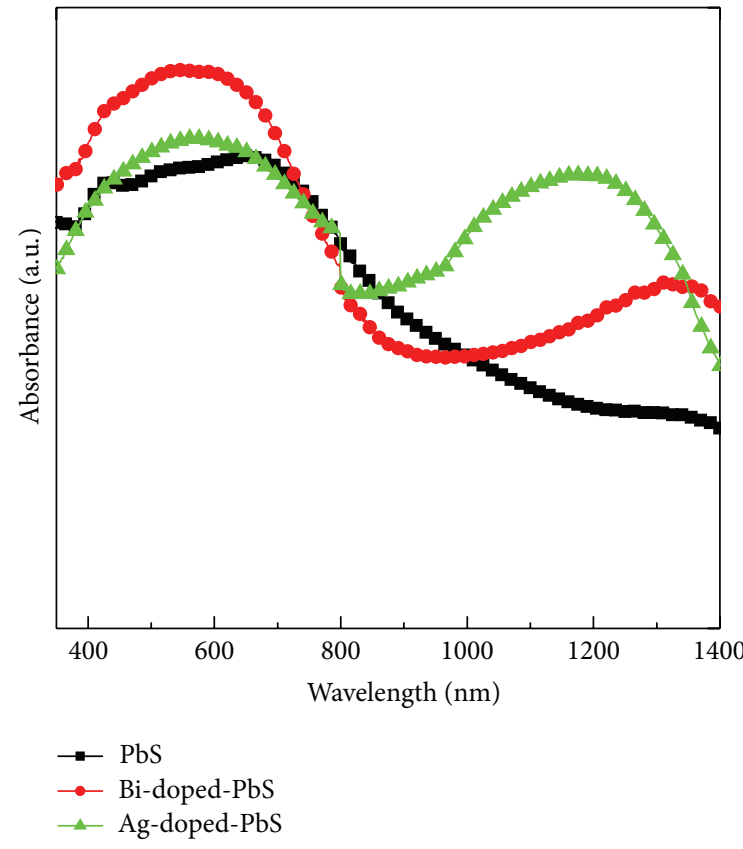

(a)

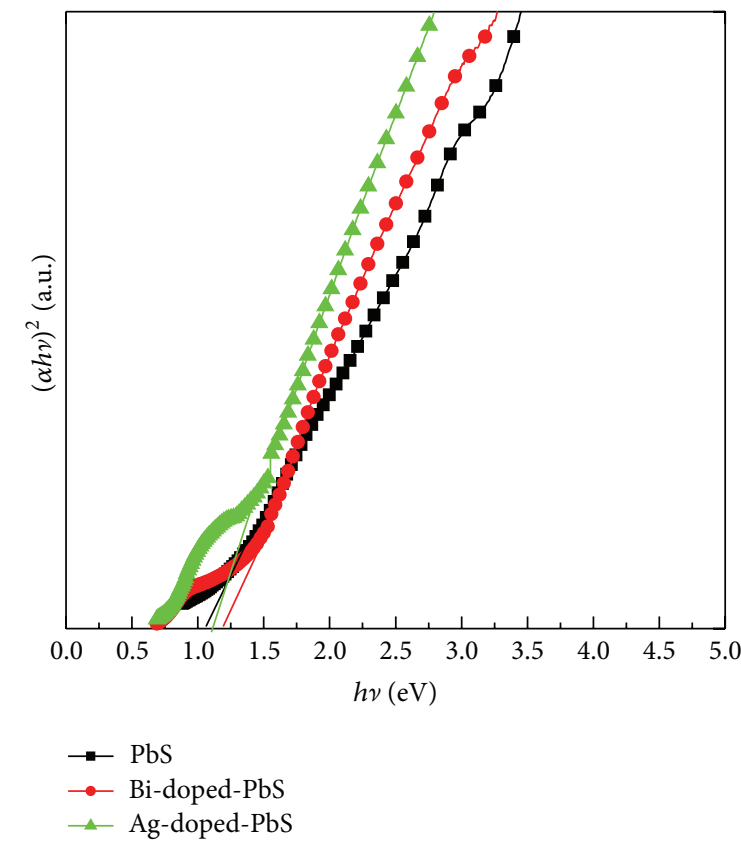

(b)

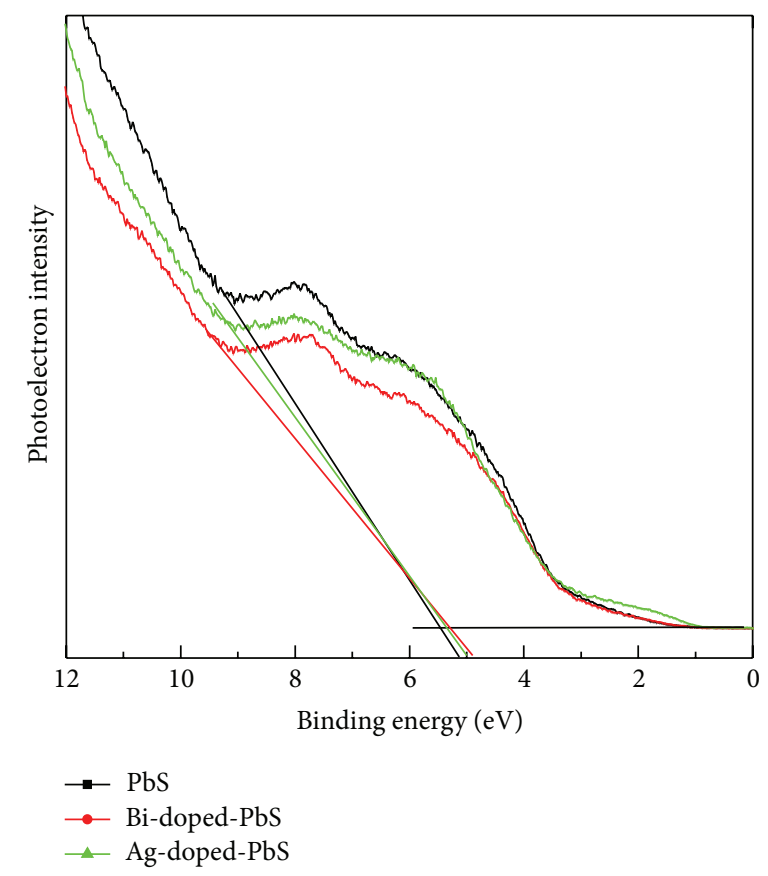

(c)

Figure 5: (a) Diffuse reflection absorption spectra, (b) the plot calculated by using $\alpha h v=A\left(h v-E_{g}\right)^{2}$ equation from absorption spectra, and (c) UPS spectra of PbS, Bi-doped-PbS, and Ag-doped-PbS QDs.

TABLE 4: Photovoltaic performances extracted from current-voltage measurements of different working electrodes.

\begin{tabular}{lcccc}
\hline Device & $J_{\text {sc }}{ }^{\mathrm{a}} / \mathrm{mAcm}^{-2}$ & $V_{\text {oc }}{ }^{\mathrm{b}} / \mathrm{V}$ & $\mathrm{FF}^{\mathrm{c}}$ & $\mathrm{PCE}^{\mathrm{d}} / \%$ \\
\hline $\mathrm{PbS}(2) / \mathrm{CdS}(7)$ & 13.929 & 469.261 & 0.357 & 2.337 \\
$1-20 \mathrm{PbS}: \mathrm{Bi}(2) / \mathrm{CdS}(7)$ & 16.108 & 431.842 & 0.341 & 2.373 \\
$\mathrm{PbS}(2) / \mathrm{CdS}(6)$ & 12.195 & 461.9 & 0.382 & 2.153 \\
$1-150 \mathrm{PbS}: \mathrm{Ag}(2) / \mathrm{CdS}(6)$ & 14.825 & 427.549 & 0.351 & 2.224 \\
\hline
\end{tabular}

${ }^{\mathrm{a}} J_{\text {sc }}$ : short-circuit photocurrent density, ${ }^{\mathrm{b}} V_{\mathrm{oc}}$ : open-current voltage, ${ }^{\mathrm{c}} \mathrm{FF}$ : fill factor, and ${ }^{\mathrm{d}} \mathrm{PCE}$ : power conversion efficiency. 


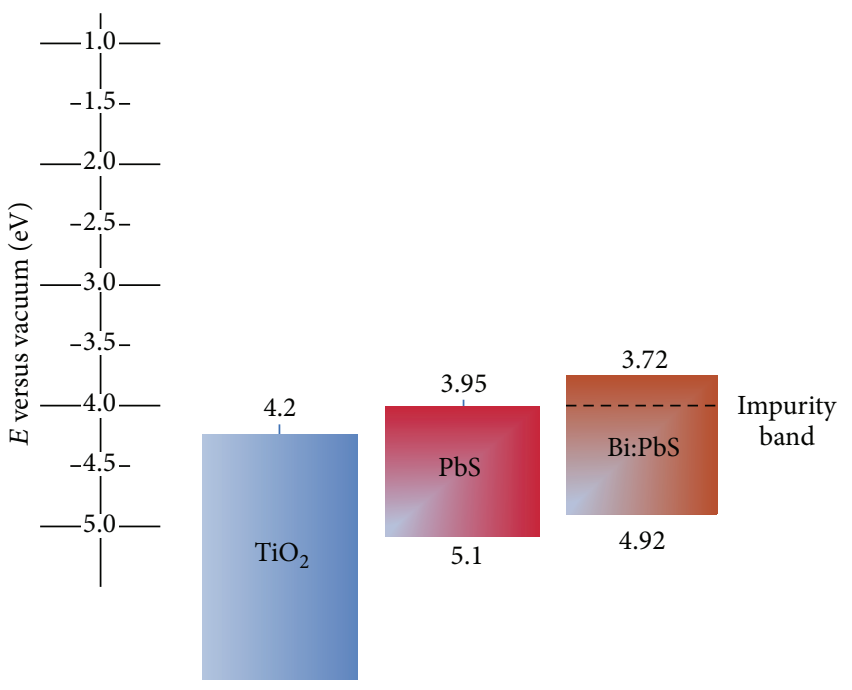

(a)

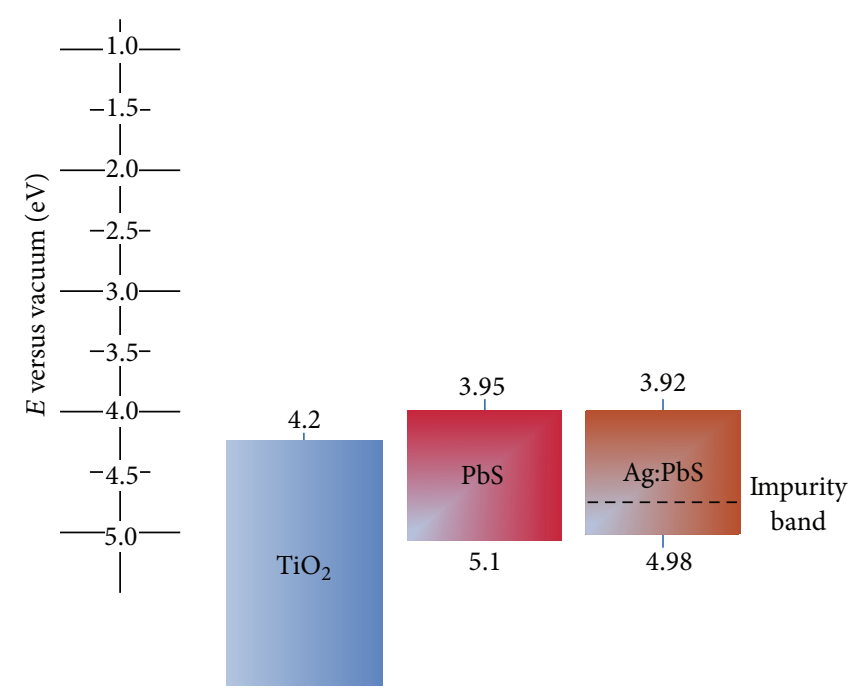

(b)

Figure 6: Band edge alignment diagram for (a) Bi-doped-PbS and (b) Ag-doped-PbS QDs.

TABLE 5: $R_{s}, R_{c}$, and $R_{\mathrm{ct}}$ values of undoped and doped QDCSCs.

\begin{tabular}{lccc}
\hline Device & $R_{s}{ }^{\mathrm{a}}(\Omega)$ & $R_{c}{ }^{\mathrm{b}}(\Omega)$ & $R_{\mathrm{ct}}{ }^{\mathrm{c}}(\Omega)$ \\
\hline $\mathrm{PbS}(2) / \mathrm{CdS}(7)$ & 23.57 & 71.08 & 26.83 \\
1-20PbS:Bi(2)/CdS(7) & 22.1 & 38.65 & 20.3 \\
$\mathrm{PbS}(2) / \mathrm{CdS}(6)$ & 25.86 & 165.8 & 26.12 \\
$1-150 \mathrm{PbS}: \operatorname{Ag}(2) / \mathrm{CdS}(6)$ & 16.33 & 130.7 & 10.76 \\
\hline
\end{tabular}

${ }^{\mathrm{a}} R_{s}$ : series resistances, ${ }^{\mathrm{b}} R_{c}$ : electronic transfer resistances of $\mathrm{TiO}_{2} / \mathrm{QDs}$ and electrolyte interface, and ${ }^{\mathrm{c}} R_{\mathrm{ct}}$ : electronic transfer resistances of photocathode and the electrolyte solution interface.

can be influenced by the value of monochromatic incident photon-to-electron conversion efficiency (IPCE) and spectral response range. Doping of $\mathrm{Bi}$ or $\mathrm{Ag}$ impurities into $\mathrm{PbS} \mathrm{QDs}$ leads to improvement of the value of IPCE and broadening of spectral response range, according to IPCE spectra (Figure 7(c)) resulting in the increase of $J_{\mathrm{SC}}$. Besides, for the two systems, $V_{\mathrm{OC}}$ is degraded as photocurrent increases, and this may be because of the decreased shunt resistance. The fill factors are degraded which may be due to the $V_{\mathrm{OC}}$ being degraded. Thus power conversion efficiency is slightly improved through doping $\mathrm{Bi}$ or $\mathrm{Ag}$ impurities into PbS QDs.

The electrochemical impedance spectroscopy (EIS) is shown in Figure $7(\mathrm{~d})$. The series resistances $\left(R_{s}\right)$ and the electronic transfer resistances of $\mathrm{TiO}_{2} / \mathrm{QDs}$ and electrolyte interface $\left(R_{c}\right)$ and photocathode and the electrolyte solution interface $\left(R_{\mathrm{ct}}\right)$ are summarized in Table 5 derived from the spectra by using the equivalent circuit [15]. The $R_{s}$ and $R_{c}$ decrease after doping $\mathrm{Bi}^{3+}$ and $\mathrm{Ag}^{+}$, indicating that the charge transfer resistance reduces in doped QDCSCs. However, the decreased $R_{\mathrm{ct}}$ values increase the electronic transfer resistances. Thus, the PCE of doped QDCSCs is slightly improved.

Schematic structure of the PbS, Bi-doped-PbS, and Agdoped-PbS QDs is shown in Figure 8, according to results of optical measurements, XPS, Hall measurement, and reported articles $[8,16]$. The radius of $\mathrm{Bi}^{3+}$ is equal to the clearance radius of $\mathrm{PbS}$ cubes [16] which are shown in Table 6 , so the $\mathrm{Bi}^{3+}$ can enter into the cube clearance to form interstitial doping. We infer that the $(\mathrm{Pb}-\mathrm{S})$ bonds are reinforced by doping $\mathrm{Bi}^{3+}$, which contribute not only to a decrease of the lattice size but to the increase of the optical band gap of $\mathrm{PbS}$ QD. The radius of $\mathrm{Ag}^{+}$is a little smaller than the clearance radius of $\mathrm{PbS}$ cubes and is equal to the radius of $\mathrm{Pb}^{2+}$; thus, $\mathrm{Ag}^{+}$can substitute for $\mathrm{Pb}^{2+}$ to form replacement doping, leading to lattice contraction. However, the breaking of $(\mathrm{Pb}-$ $S$ ) bonds makes lattice expansion. These two kinds of function cause a little lattice distortion and the size of Ag-doped-PbS is unchanged.

Based on optical measurements, UPS, and Hall measurement, we inferred the internal mechanism of QDCSCs and doped QDCSCS to explain the changes of performance for QDCSCs after doping. From Figure 9, the significant difference in doped QDCSCs is that there is impurity band in doped-PbS QDs. The PbS and CdS QDs can both absorb light, leading to the separation of electron-hole. For Bi-doped$\mathrm{PbS}$ QDCSSC, the photogenerated electrons generated from impurity band can be transferred to the $\mathrm{CBM}$ of $\mathrm{TiO}_{2}$, which means that $\mathrm{Bi}$ is donor impurity contributing electrons. For $\mathrm{Ag}$-doped-PbS, the photogenerated electrons generated from CdS not only can be transferred to the $\mathrm{CBM}$ of $\mathrm{TiO}_{2}$ but also to the $\mathrm{Ag}$ impurity band possibly, which means that $\mathrm{Ag}$ is acceptor impurity contributing holes. This means that there is higher probability recombination of electrons in impurity band leading to the decrease of Rc for doped-PbS QDCSC.

\section{Conclusions}

Heavily doped-PbS QDs were prepared by doping cations $\mathrm{Bi}^{3+}$ and $\mathrm{Ag}^{+}$and the existence form of impurities is interstitial or substitutional doping. The cation $\mathrm{Bi}^{3+}$ entered the cube space of $\mathrm{PbS}$ as donor yielding interstitial doping $\mathrm{Bi}$ doped-PbS QD, and $\mathrm{Ag}^{+}$replaced $\mathrm{Pb}^{2+}$ of $\mathrm{PbS}$ as acceptor 

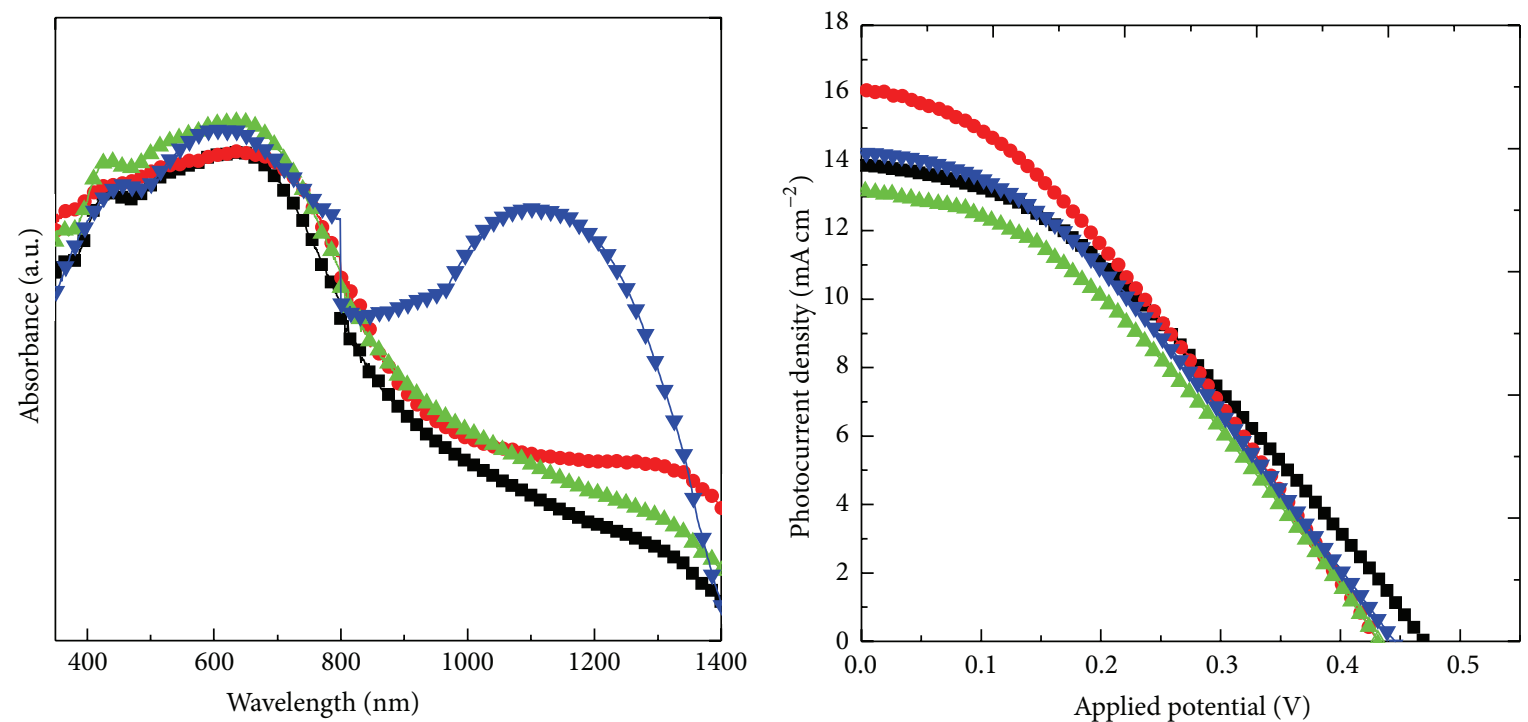

$\rightarrow-\mathrm{TiO}_{2} / \mathrm{PbS}(2) / \mathrm{CdS}(7)$

$\rightarrow \mathrm{TiO}_{2} / \mathrm{Bi}$-doped-PbS-Ag(2)/CdS(7)

$\sim-\mathrm{TiO}_{2} / \mathrm{PbS}(2) / \mathrm{CdS}(6)$

$\rightarrow \mathrm{TiO}_{2} / \mathrm{Ag}$-doped-PbS(2)/CdS(6)

(a)

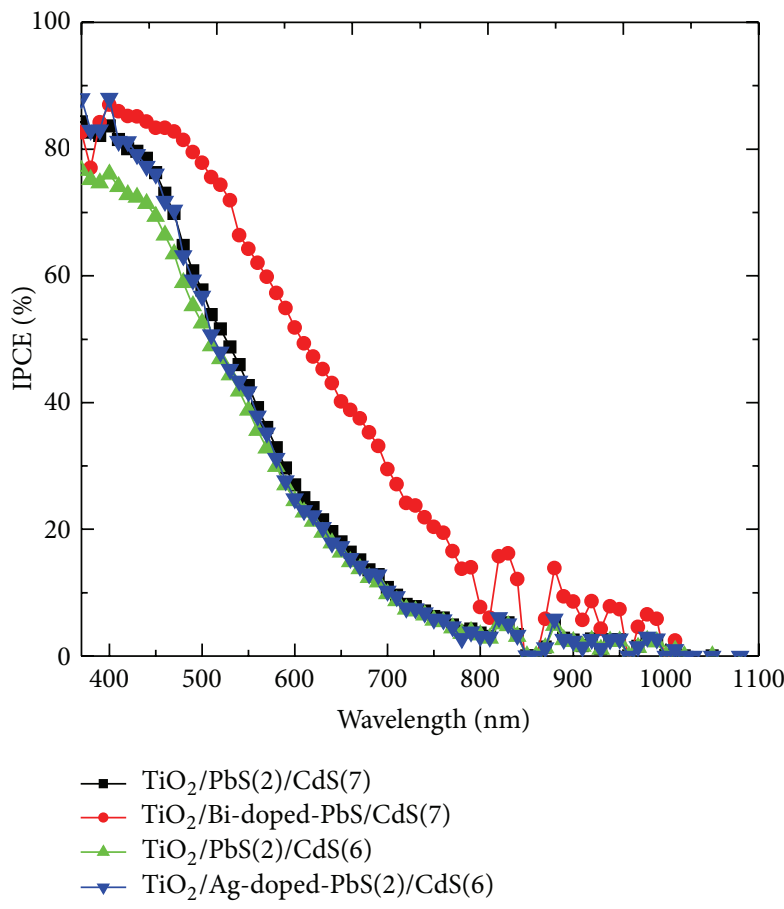

(c)

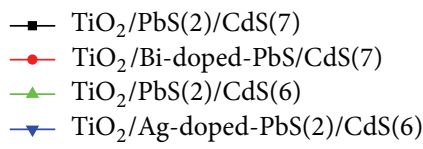

(b)

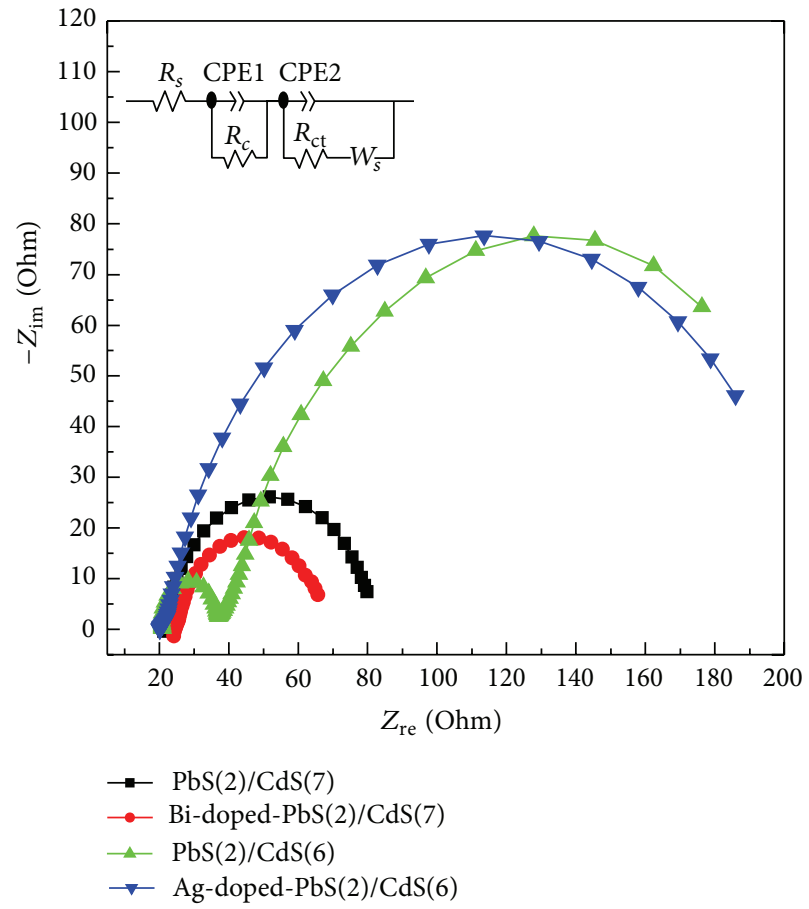

(d)

Figure 7: (a) Diffuse reflection absorption spectra of photoanode, (b) $J$ - $V$ curves, (c) IPCE spectra, and (d) EIS spectra of $\mathrm{TiO}_{2} / \mathrm{PbS}(2) / \mathrm{CdS}(7), \mathrm{TiO}_{2} / \mathrm{Bi}$-doped-PbS(2)/CdS(7), $\mathrm{TiO}_{2} / \mathrm{PbS}(2) / \mathrm{CdS}(6)$, and $\mathrm{TiO}_{2} /$ Ag-doped-PbS(2)/CdS QDCSCs.

TABLE 6: Size parameters of each material in the PbS lattice.

\begin{tabular}{lcccccc}
\hline Substance & PbS lattice constant & Clearance radius & Radius $\left(\mathrm{Pb}^{2+}\right)$ & $\operatorname{Radius}\left(\mathrm{Bi}^{3+}\right)$ & $\operatorname{Radius}\left(\mathrm{Ag}^{+}\right)$ & $\operatorname{Radius}\left(\mathrm{S}^{2-}\right)$ \\
\hline Size $(\AA)$ & 5.94 & $\approx>1$ & 1.19 & 1.03 & 1.15 & 1.84 \\
\hline
\end{tabular}




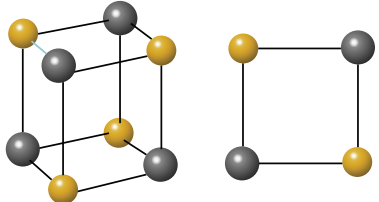

PbS QD

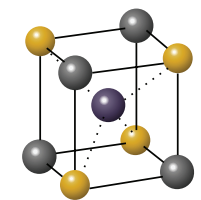

Bi-doped-PbS QD

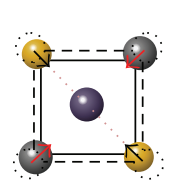

$\mathrm{PbS}$ QD

$\mathrm{Pb}$
$\mathrm{Ag}$

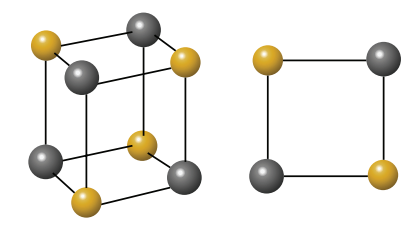

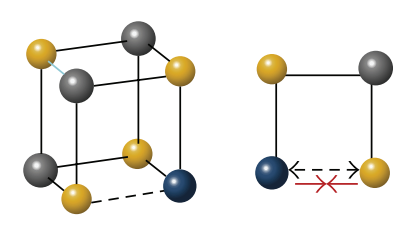

Ag-doped-PbS QD

$\mathrm{Pb}$
$\mathrm{Bi}$

(a)

(b)

FIgURE 8: The ball-stick mode of quantum dot unit cells: (a) PbS and Bi-doped-PbS and (b) PbS and Ag-doped-PbS.
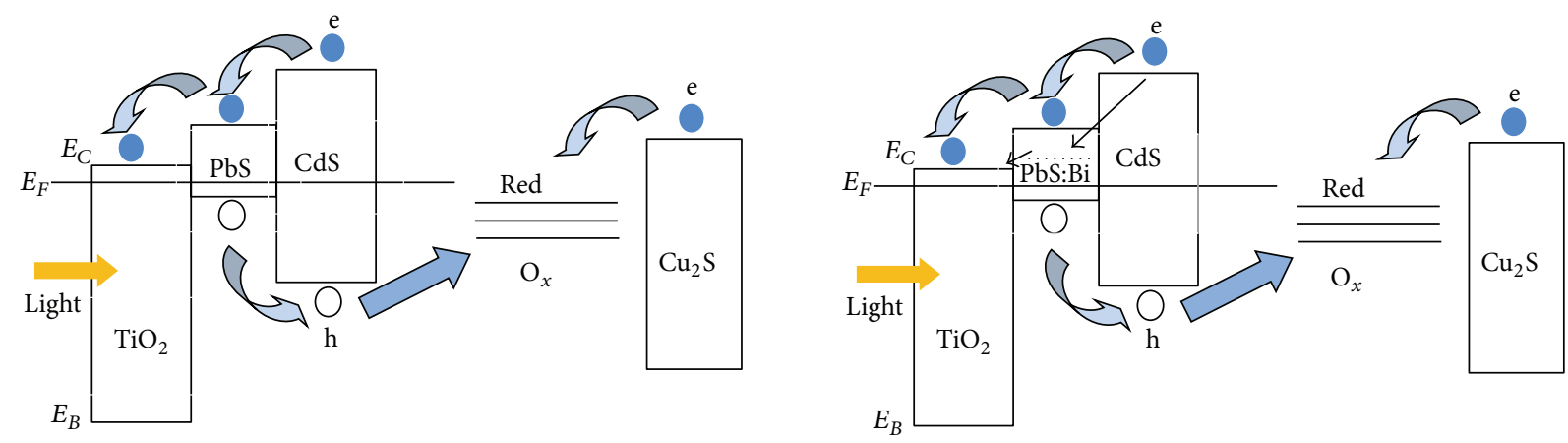

(a)
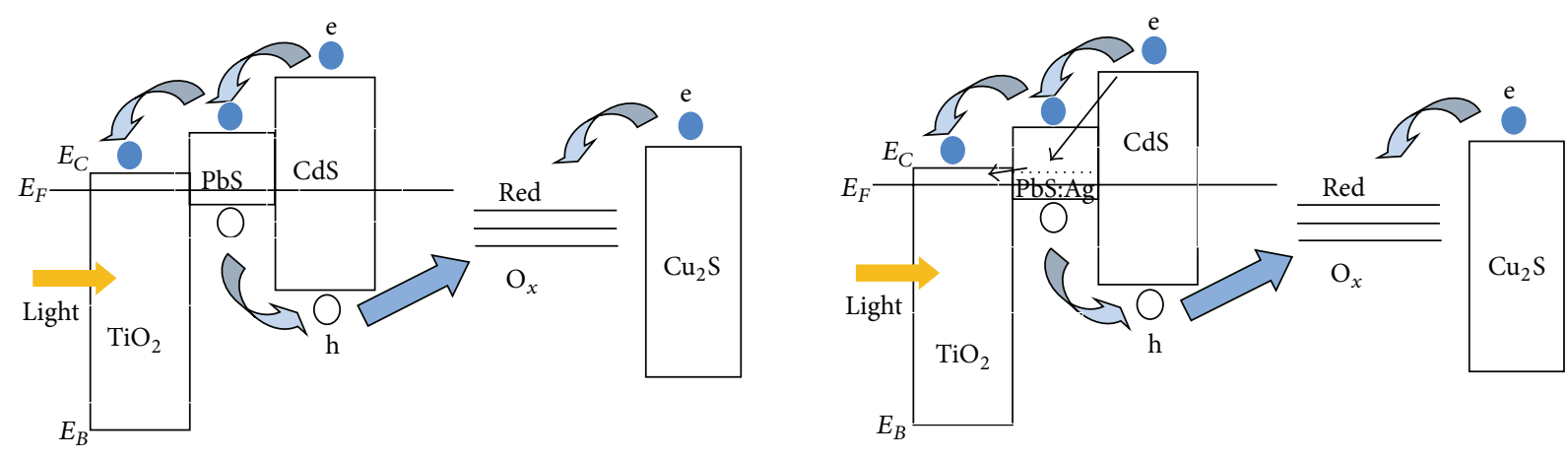

(b)

Figure 9: Schematic illustrations for internal mechanism of (a) $\mathrm{TiO}_{2} / \mathrm{PbS} / \mathrm{CdS}$ and $\mathrm{TiO}_{2} / \mathrm{Bi}$-doped-PbS/CdS and (b) $\mathrm{TiO} / 2 / \mathrm{PbS} / \mathrm{CdS}$ and $\mathrm{TiO}_{2} /$ Ag-doped-PbS/CdS QDCSCs.

yielding substitutional doping Ag-doped-PbS QD. The novel Bi-doped-PbS/CdS and Ag-doped-PbS/CdS quantum dot cosensitized solar cell (QDCSC) were assembled and PCE of $2.4 \%$ and $2.2 \%$ was obtained, respectively, under full sun illumination. The analysis of the changes of energy level of the cell has important influence upon understanding the effect of doping in theory and the development of QDSSC.

\section{Conflict of Interests}

The authors declare that there is no conflict of interests regarding the publication of this paper.

\section{Acknowledgments}

This work was partially supported by Key Project of Beijing Natural Science Foundation (3131001), Key Project of Natural Science Foundation of China (91233201 and 61376057), Key Project of Beijing Education Committee Science \& Technology Plan (KZ201211232040), State 863 Plan of MOST of PR China (2011AA050527), Beijing National Laboratory for Molecular Sciences (BNLMS2012-21), State Key Laboratory of Solid State Microstructures of Nanjing University (M27019), State Key Laboratory for New Ceramic and Fine Processing of Tsinghua University (KF1210), Key Laboratory for Renewable Energy and Gas Hydrate of Chinese Academy 
of Sciences (y207ka1001), Beijing Key Laboratory for Sensors of BISTU (KF20141077207 and KF20141077208), and Beijing Key Laboratory for Photoelectrical Measurement of BISTU (GDKF2013005).

\section{References}

[1] A. J. Nozik, M. C. Beard, J. M. Luther, M. Law, R. J. Ellingson, and J. C. Johnson, "Semiconductor quantum dots and quantum dot arrays and applications of multiple exciton generation to third-generation photovoltaic solar cells," Chemical Reviews, vol. 110, no. 11, pp. 6873-6890, 2010.

[2] J. B. Sambur, T. Novet, and B. A. Parkinson, "Multiple exciton collection in a sensitized photovoltaic system," Science, vol. 330, no. 6000 , pp. 63-66, 2010.

[3] P. V. Kamat, "Quantum dot solar cells. Semiconductor nanocrystals as light harvesters," The Journal of Physical Chemistry C, vol. 112, no. 48, pp. 18737-18753, 2008.

[4] J. Tang, K. W. Kemp, S. Hoogland et al., "Colloidal-quantum-dot photovoltaics using atomic-ligand passivation," Nature Materials, vol. 10, no. 10, pp. 765-771, 2011.

[5] A. J. Nozik, "Quantum dot solar cells," Physica E: LowDimensional Systems and Nanostructures, vol. 14, no. 1-2, pp. 115-120, 2002.

[6] W. Lee, W.-C. Kwak, S. K. Min et al., "Spectral broadening in quantum dots-sensitized photoelectrochemical solar cells based on CdSe and Mg-doped CdSe nanocrystals," Electrochemistry Communications, vol. 10, no. 11, pp. 1699-1702, 2008.

[7] P. K. Santra and P. V. Kamat, "Mn-doped quantum dot sensitized solar cells: a strategy to boost efficiency over 5\%," Journal of the American Chemical Society, vol. 134, no. 5, pp. 2508-2511, 2012.

[8] J.-W. Lee, D.-Y. Son, T. K. Ahn et al., "Quantum-dot-sensitized solar cell with unprecedentedly high photocurrent," Scientific Reports, vol. 3, article 1050, 2012.

[9] A. Stavrinadis, A. K. Rath, F. P. G. de Arquer et al., "Heterovalent cation substitutional doping for quantum dot homojunction solar cells," Nature Communications, vol. 4, article 2981, 2013.

[10] R. A. Abram, G. J. Rees, and B. L. H. Wilson, "Heavily doped semiconductors and devices," Advances in Physics, vol. 27, no. 6, pp. 799-892, 1978.

[11] D. Mocatta, G. Cohen, J. Schattner, O. Millo, E. Rabani, and U. Banin, "Heavily doped semiconductor nanocrystal quantum dots," Science, vol. 332, no. 6025, pp. 77-81, 2011.

[12] A. Kongkanand, K. Tvrdy, K. Takechi, M. Kuno, and P. V. Kamat, "Quantum dot solar cells. Tuning photoresponse through size and shape control of $\mathrm{CdSe}-\mathrm{TiO}_{2}$ architecture," Journal of the American Chemical Society, vol. 130, no. 12, pp. 4007-4015, 2008.

[13] S. Tsunekawa, T. Fukuda, and A. Kasuya, "Blue shift in ultraviolet absorption spectra of monodisperse $\mathrm{CeO}_{2}$ - $\mathrm{x}$ nanoparticles," Journal of Applied Physics, vol. 87, no. 3, pp. 1318-1321, 2000.

[14] B. Carlson, K. Leschkies, E. S. Aydil et al., "Valence band alignment at cadmium selenide quantum dot and zinc oxide (1010) interfaces," Journal of American Chemical Society, vol. 112, pp. 8419-8423, 2008.

[15] R. D. Shannon, "Revised effective ionic radii and systematic studies o interatomic distances in halides and chalcogenides," Acta Crystallographica A, vol. 32, no. 5, pp. 751-767, 1976.

[16] M. H. Deng, S. Q. Huang, Q. X. Zhang et al., "Screen-printed $\mathrm{Cu}_{2} \mathrm{~S}$-based counter electrode for quantum-dot-sensitized solar cell," Chemistry Letters, vol. 39, no. 11, pp. 1168-1170, 2010. 

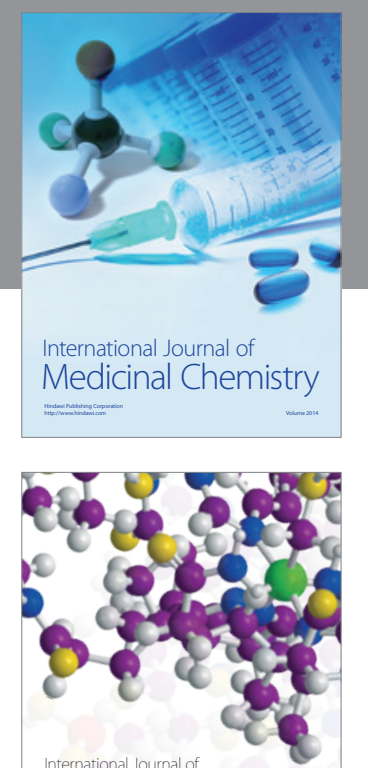

\section{Carbohydrate} Chemistry

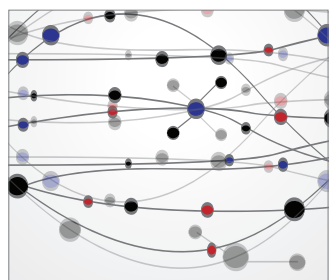

The Scientific World Journal
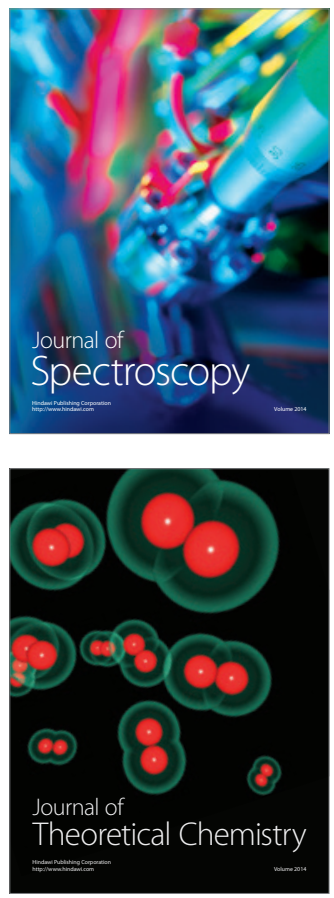
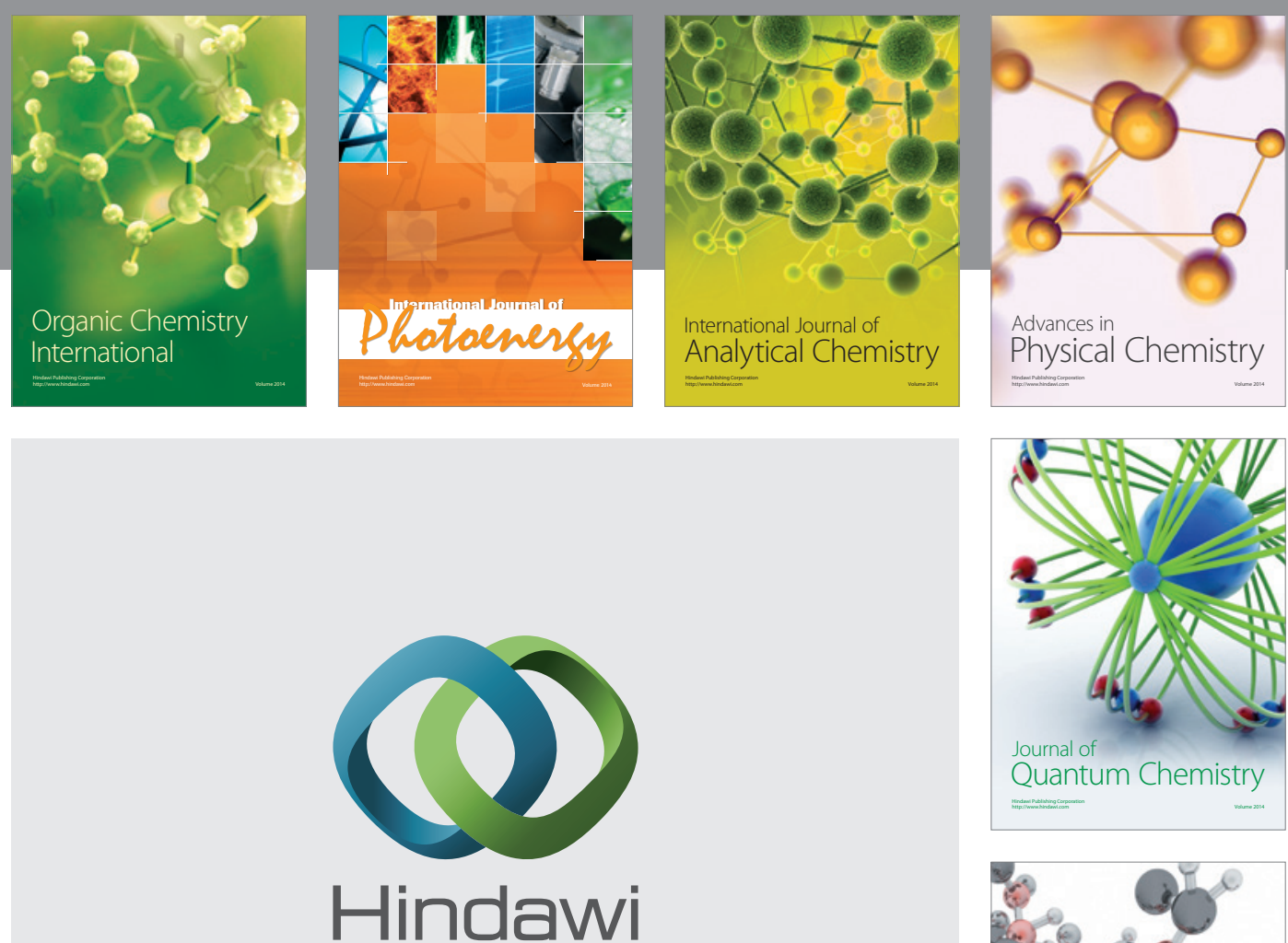

Submit your manuscripts at

http://www.hindawi.com

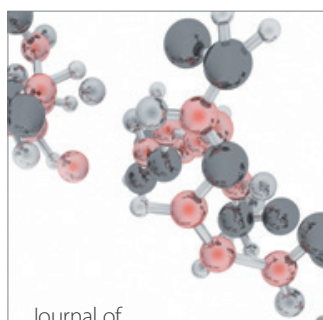

Analytical Methods

in Chemistry

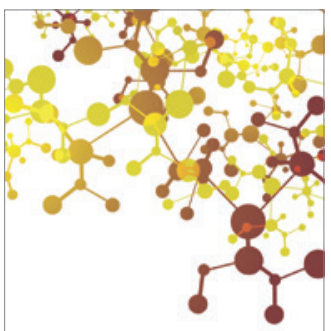

Journal of

Applied Chemistry

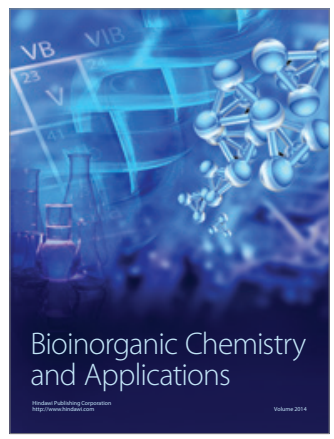

Inorganic Chemistry
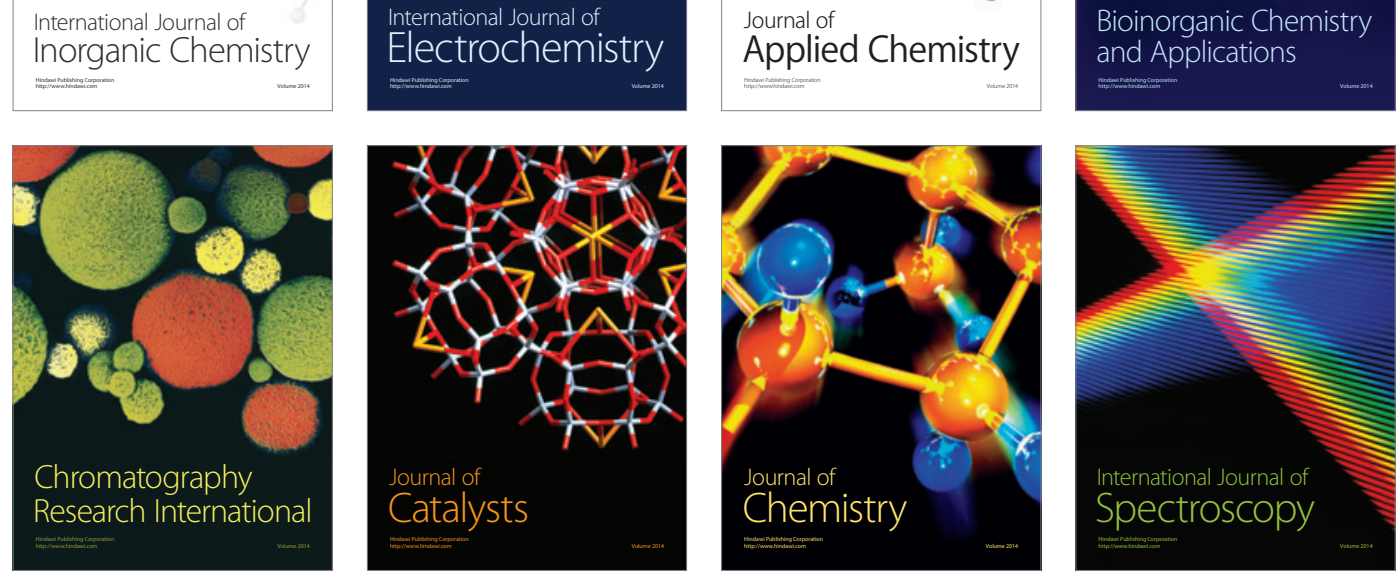